\title{
Performance of two promising mutants of sesame under some on- station and on-farm environments
}

\author{
M. A. Malek and F. I. Monshi \\ Plant Breeding Division, Bangladesh Institute of Nuclear Agriculture, BAU Campus, Mymensingh-2202, \\ Bangladesh
}

\begin{abstract}
An experiment was conducted in different farms of BINA sub-station at Magura and Ishurdi and in the farmers' field at Nachole upazila of Chapai Nowabgonj and Tetulia upazila of Panchagor during kharif-I to evaluate the performance of sesame mutant lines (SM-5 and SM-12). The tested parameters included: plant height, branches per plant, capsules per plant, seeds per capsule, days to maturity and yield per ha. Highly significant variations were observed both in individual location and combined over locations for all traits except number of capsules per plant in on-station trial. On the other hand, highly significant variations were observed for all traits except capsules per plant in Nachole upazila of Chapai Nowabgonj and combined over locations. The mutant line SM-12 can be registered as a new variety of sesame in respect of higher number of branches per plant, capsules per plant and higher seed yield.
\end{abstract}

Keyword: Mutant, Sesame, On-station, On-farm

\section{Introduction}

Sesame (Sesamum indicum), an ancient oilseed, is one of the oldest cultivated plants in the world. This warm-season annual crop is primarily adapted to areas with long growing seasons and welldrained soils and has spread from its center of origin in Iraq to many parts of the world. Sesame is an important oil crop in Bangladesh. The area and the production of sesame are 0.58 lakh hectares and 0.66 lakh tons, respectively (AIS, 2008). Sesame seeds are unusually high in oil, around $50 \%$ of the seed weight. Sesame is a fairly high value food crop, being harvested both for whole seed used in baking, and for the cooking oil extracted from the seed.

Mutation breeding is an effective tool to induce mutations in different qualitative characters of crop species (Gregory, 1955; Gaul, 1974; Bhatia, 1991). Mutation breeding has already led to improved cultivars with higher yield, better grain quality, or stronger resistance to pathogenens (El-Bramawy and Shaban, 2007). The mutants after proper evaluation and selection need to be further tested in different agro-ecological zones to determine its general and location-specific suitability for utilization (Ottai et. al., 2005). This experiment was undertaken to evaluate the performance of two newly developed mutants of sesame in the farms of BINA sub-station at Magura and Ishurdi and in the farmers' field at Nachole upazila of Chapai Nowabgonj and Tetulia upazila of Panchagor districts.

\section{Materials and Methods}

The trials were carried out in the farms of BINA sub-station at Magura and Ishurdi and in the farmers' field at Nachole upazila of Chapai Nowabgonj and Tetulia upazila of Panchagor during kharif-I of 2008. Two advanced mutant lines (SM-5 and SM-12) and two check varieties (Binatil-1 and Baritil-2) were included in the test. The experiment was laid out in a randomized complete block design with four replications. Unit plot size was $25 \mathrm{~m}^{2}(5 \mathrm{~m} \times 5 \mathrm{~m})$ with $25 \mathrm{~cm}$ spacing between rows and 8-10 cm between plants in a row. Seeds were sown from the last week of February to 15 March 2008. Recommended management packages were followed for on-station trials while farmers' practices with recommended doses of fertilizers, one or no irrigation with poor cultural managements were followed for farmers' field trials. Data were taken for plant height, branches per plant, capsules per plant and seeds per capsule from 10 randomly selected plants of each plot. Days to maturity was counted when $80 \%$ capsules were matured and turned into yellowish colour in each plot. Seed yield of each plot was recoded after harvest and then converted into $\mathrm{kg} / \mathrm{ha}$. Appropriate statistical analyses were performed and the mean values of each character were compared. Mean differences of different parameters were tested by Duncan's Multiple Range Test (Gomez and Gomez, 1984). 


\section{Results and Discussion}

\section{Results for on-station trial}

A significant variation was observed on the plant height in both locations. At Magura, Binatil-1 produced the tallest plant $(126 \mathrm{~cm})$ followed by SM-12 $(122 \mathrm{~cm})$ while SM-5 produced the shortest plant $(100 \mathrm{~cm})$. At Ishurdi, Binatil-1 produced the tallest plant $(113 \mathrm{~cm})$ while $S M-5$ produced the shortest plant $(96 \mathrm{~cm})$ (Table 1).

Number of branches per plant was significantly difference in both locations. At Magura, Binatil-2 produced the highest number of branches per plant (3.1) followed by mutant line SM-12 (2.9) while Binatil-1 and SM-5 were unicum. Mutant line SM-12 produced higher number of branches (3.2) per plant followed by Baritil-2 (3.1) and SM-5 (2.5) whereas the control variety Binatil-1 was unicum at Ishurdi (Table 1).

Number of capsules per plant, one of the yield contributing characters in sesame was significantly difference in both locations. At Magura, Binatil-1 produced the highest number of capsules per plant (63) followed by mutant line SM-12 (52) whereas Baritil-2 produced the lowest number of capsules (44). At Ishurdi, mutant line SM-12 produced the highest number of capsules per plant (65) followed by Baritil-2 (64) while lowest was in SM-5 (58) (Table 1).

A significant variation was found on the number of seeds per capsules in both locations. At Magura, Binatil-1 produced the highest number of seeds per capsule (86) while lowest was found in Baritil-2 (70). In Ishurdi, the highest number of seeds per capsule (75) was produced in Binatil-1 followed by SM-5 (62) whereas lowest (61) was in SM-12 and Baritil-2 (Table 1).

A significantly difference was observed on days to maturity in both locations. Baritil-2 needed the longest duration (79 days) followed by Binatil-1 (77 days) while mutant SM-5 needed the shortest duration (71 days) at Magura. Mutant line, SM-12 needed long duration (96 days) followed by Baritil-2 (95 days) while mutant SM-5 needed possible short duration (91 days) at Ishurdi (Table 1).

Seed yield, the most important characters in sesame, was significantly difference in both locations. At Magura, SM-12 produced the highest seed yield (2047 kg/ha) followed by Binatil-1 (2004 kg/ha) whereas SM-5 produced the lowest seed yield (1761 kg/ha). At Ishurdi, SM-12 produced the highest seed yield (1692 kg/ha) followed by Binatil-1 (1563 kg/ha) whereas SM-5 produced the lowest seed yield $(1116 \mathrm{~kg} / \mathrm{ha})$. Between two locations, seed yield at Magura was better along with yield components (Table 1).

\section{Results for on-farm trials}

A significant variation was observed on the plant height in both locations. At Nachole, Binatil-1 produced the tallest plant $(108 \mathrm{~cm})$ followed by SM-12 and Baritil-2 $(97 \mathrm{~cm})$ while SM-5 produced the shortest plant $(83 \mathrm{~cm})$. At Tetulia, Binatil-1 produced the tallest plant $(97 \mathrm{~cm})$ while mutant lines, $S M-5$ and SM-12 produced the shortest plant $(85 \mathrm{~cm})($ Table 1$)$.

Number of branches per plant was significantly difference in both locations. At Nachole, Binatil-2 produced the highest number of branches (3.5) per plant followed by mutant line SM-12 (3.3) while Binatil-1 was unicum. Mutant line SM-12 produced higher number of branches (3.3) per plant followed by Baritil-2 (2.9) whereas the control variety Binatil-1 was unicum in Tetulia (Table 1).

At Nachole, Binatil-1 produced the highest number of capsules (54) per plant followed by Baritil-2 (53) whereas SM-5 produced the lowest number of capsules (46). At Tetulia, mutant line SM-12 produced the highest number of capsules (52) per plant followed by Binatil-1 (49) while lowest was in Baritil-2 (44) (Table 1).

A significant variation was found on the number of seeds per capsules in both locations. At Nachole, Binatil-1 produced the highest number of seeds (86) per capsules while lowest was found in Baritil-2 (70). At Tetulia, the highest number of seeds (75) per capsules was produced in Binatil-1 followed by SM-5 (63) whereas lowest (57) was in Baritil-2 (Table 1). 
A significantly difference was observed on days to maturity in both locations. Baritil-2 needed long duration (97 days) followed by SM-12 (96 days) while mutant SM-5 needed possible short duration (87 days) in Nachole. Mutant line SM-12 needed long duration (96 days) followed by Baritil-2 (95 days) while mutant SM-5 needed possible short duration (86 days) in Tetulia (Table 1).

Table 1. Mean of mutant lines and check varieties for different quantitative characters

\begin{tabular}{|c|c|c|c|c|c|c|}
\hline $\begin{array}{l}\text { Mutants/ } \\
\text { varieties }\end{array}$ & $\begin{array}{l}\text { Plant height } \\
(\mathrm{cm})\end{array}$ & $\begin{array}{l}\text { No. of } \\
\text { branches/ } \\
\text { plant }\end{array}$ & $\begin{array}{c}\text { No. of } \\
\text { capsules/ } \\
\text { plant }\end{array}$ & $\begin{array}{c}\text { No. of } \\
\text { seeds/ } \\
\text { capsule }\end{array}$ & $\begin{array}{l}\text { Days to } \\
\text { maturity }\end{array}$ & $\begin{array}{c}\text { Yield } \\
\text { (kg/ha) }\end{array}$ \\
\hline \multicolumn{7}{|c|}{ On-station trial: } \\
\hline \multicolumn{7}{|l|}{ Magura } \\
\hline SM-5 & $100^{C}$ & $0.0^{b}$ & $49^{b}$ & $80^{\mathrm{ab}}$ & $71^{\mathrm{c}}$ & $1761^{\mathrm{C}}$ \\
\hline SM-12 & $122^{\mathrm{a}}$ & $2.9^{\mathrm{a}}$ & $52^{b}$ & $73^{\mathrm{bc}}$ & $76^{b}$ & $2047^{a}$ \\
\hline Binatil-1 & $126^{\mathrm{a}}$ & $0.0^{b}$ & $63^{\mathrm{a}}$ & $86^{a}$ & $77^{b}$ & $2004^{a b}$ \\
\hline Baritil-2 & $113^{b}$ & $3.1^{\mathrm{a}}$ & $44^{b}$ & $70^{\mathrm{C}}$ & $79^{a}$ & $1913^{b}$ \\
\hline \multicolumn{7}{|l|}{ Ishurdi } \\
\hline SM-5 & $96^{\mathrm{C}}$ & $2.5^{\mathrm{b}}$ & 58 & $62^{b}$ & $91^{c}$ & $1116^{\mathrm{C}}$ \\
\hline SM-12 & $105^{b}$ & $3.2^{\mathrm{a}}$ & 65 & $61^{b}$ & $96^{\mathrm{a}}$ & $1692^{\mathrm{a}}$ \\
\hline Binatil-1 & $113^{\mathrm{a}}$ & $0.0^{\mathrm{C}}$ & 60 & $75^{a}$ & $93^{b}$ & $1563^{\mathrm{ab}}$ \\
\hline Baritil-2 & $105^{b}$ & $3.1^{\mathrm{a}}$ & 64 & $61^{b}$ & $95^{\mathrm{a}}$ & $1438^{b}$ \\
\hline \multicolumn{7}{|l|}{ On-farm trial : } \\
\hline \multicolumn{7}{|l|}{ Nachole } \\
\hline SM-5 & $83^{c}$ & $0.6^{\mathrm{b}}$ & 46 & $79^{b}$ & $87^{c}$ & $1136^{\mathrm{bc}}$ \\
\hline SM-12 & $97^{\mathrm{b}}$ & $3.3^{\mathrm{a}}$ & 50 & $71^{\mathrm{c}}$ & $96^{\mathrm{a}}$ & $1240^{\mathrm{ab}}$ \\
\hline Binatil-1 & $108^{a}$ & $0.0^{b}$ & 54 & $85^{\mathrm{a}}$ & $91^{b}$ & $1302^{\mathrm{a}}$ \\
\hline Baritil-2 & $97^{b}$ & $3.5^{\mathrm{a}}$ & 53 & $70^{c}$ & $97^{\mathrm{a}}$ & $1115^{\mathrm{C}}$ \\
\hline \multicolumn{7}{|l|}{ Tetulia } \\
\hline SM-5 & $85^{b}$ & $0.5^{b}$ & $48^{\mathrm{ab}}$ & $63^{b}$ & $86^{c}$ & $1271^{b c}$ \\
\hline SM-12 & $85^{b}$ & $3.3^{a}$ & $52^{a}$ & $61^{b c}$ & $96^{a}$ & $1313^{\mathrm{ab}}$ \\
\hline Binatil-1 & $97^{a}$ & $0.0^{b}$ & $49^{a}$ & $75^{a}$ & $91^{b}$ & $1388^{a}$ \\
\hline Baritil-2 & $88^{b}$ & $2.9^{\mathrm{a}}$ & $44^{b}$ & $57^{\mathrm{C}}$ & $95^{a}$ & $1194^{\mathrm{C}}$ \\
\hline
\end{tabular}

$\mathrm{SM}=$ Sesame mutant

abc Means with different superscript in the same column differ significantly.

Seed yield, the most important characters in sesame, was significantly difference in both locations. At Nachole, Binatil-1 produced the highest seed yield (1302 kg/ha) followed by SM-12 (1240 kg/ha) whereas Baritil-2 produced the lowest seed yield (1115 kg/ha). At Tetulia, Binatil-1 produced the highest seed yield $(1388 \mathrm{~kg} / \mathrm{ha})$ followed by SM-12 (1313 kg/ha) whereas Baritil-2 produced the lowest seed yield (1194 kg/ha).

Between the two locations, Tetulia showed better performance than Nachole in respect of seed yield (Table 1). Improvement in different quantitative characters as discussed above through induced mutation technique has also been reported earlier by many researchers (Mickle et al., 1987; Novak and Brunner, 1992; Rahman et al., 1992; Zakri, 1991).

From the above experimental results, it can be said that mutation breeding is the most relevant tool to create genetic variations in quantitative characters of plant species which have narrow genetic base. Thus, plant breeders could get a good scope for selection of mutation with desirable characters, such as with early maturing mutants with tolerance to stresses (salinity and drought) and high seed yield and oil content. Kamala and Sasikala (1985) reported that they developed some high yielding sesame mutants which contained more oil than the control.

In respect of number of branches per plant, number of capsules per plant and higher seed yield in mutant line SM-12 can be registered as a new sesame variety for cultivation all over the country. 


\section{References}

AIS (Agricultural Information Service). 2008. Krishi Diary. Agril. Infor. Ser. Khamarbari, Farmgate, Dhaka. Bangladesh. p. 35.

Bhatia, C.R. 1991. Economic impact of mutants varieties in India. In: Plant Mutation Breeding for Crop Improvement. vol. J. Proc. Symp. FAO/IAEA, Vienna,18-22 June, 1990. pp.33-46.

El-Bramawy, M.A.S. and Shaban, W.I. 2007. Nature of Gene Action for Yield, Yield Components and Major Diseases Resistance in Sesame (Sesamum indicum L.) Res. J. Agric. Biol. Sci., 3(6): 821-826.

Gaul, H. 1974. Use of induced mutants in seed propagated species. Mutation and Plant Breeding. Nat. Acad. Sci., Nat. Res. council, USA.pp. 206-252.

Gomez, K.A. and Gomez, A.A. 1984. Statistical Procedure for Agricultural Research. $2^{\text {nd }}$ Edn. John Wiley and Sons, New York. 97-411.

Gregory, W.C. 1955. X-ray breeding of peanuts (Arachis hypogaea L.). Agron. J. 47:396-399.

Kamala, T. and Sasikala, S. 1985. Gamma ray and colchicine-induced mutants in "TMV 5" and "JS103" Sesamum. Indian J. Agric. Sci. 55(3):151-15.

Micke, A., Donini, B. and Maluzynski, M. 1987. Induced mutations for crop improvement- a review. Trop. Agric. 64: $259-278$.

Novak, F.J. and Burnner, H. 1992. Plant breeding: Induced technology for improvement. IAEA Bull. 4: 25-33.

Ottai, M.E.S., Ibrahim, M.M. and Hassanein, M.S. 2005 . Performance of different sesame (Sesamum indicum L.) varieties under variable environments. Ann. Agric. Sci. 50(1): 229-245.

Rahman, A., Das, M.L. and Pathan, M.A.J. 1992. New high yielding mutant varieties of mustard (Brassica campestris L. var. Yellow Saron). J. Nuclear Agric. Biol. (India): 21 (4) : 281-285.

Zakri, A.H. 1991. Breeding high yielding soybean varieties using induced mutation. In : Mutation Breeding for Crop Improvement. Vol. 2. Proc. Symp. FAO/IAEA, Vienna, 18-22 June, 1990. pp. 163-170. 